\title{
Universities and Globalisation Flows: African Experience
}

\author{
Nkechi Okoli* \\ Educational Foundations, University of Port Harcourt, Port Harcourt, Nigeria \\ *Corresponding author: majesse4live@yahoo.com
}

Received March 03, 2013; Revised March 18, 2013; Accepted April 05, 2013

\begin{abstract}
The study x-rays the damaging effects of brain drain on university education in Africa as a result of colonisation and globalisation. Despite its positive impact, globalisation has divided the world into the superrich and absolutely poor. Africa is the poorest of the poor. This is supported by Capitalism and the Marxist Theory. The study highlights the fact that Africa's loss of her talented brains dates back to the $16^{\text {th }}$ century. Today, globalisation has worsened the situation and has given rise to the emergence of supranational institutions as well as neo-liberalism. The study posits that although the human being is a nation's most important resource, and that human resource is central to economic development, globalisation pressure has damaging effects on poor countries and Africa in particular. Globalisation has permeated the phenomenal world of individuals, creating rifts in various segments of the nation especially in the universities, giving rise to the flight of talents, commonly called brain-drain. The need for Africa to develop credible strategy for progress in the areas that led the cream of her society to leave is highlighted. It is also pointed out that the strategy must address and explore various areas such as economic development, giving space to develop and expand the entrepreneurial talents. Africans in Diaspora should explore ways they can help their continent through diasporic spheres.
\end{abstract}

Keywords: universities, globalisation, Africa, flows, scapes, brain drain

\section{Introduction}

The study focuses on the fact that globalisation flows have dealt devastating blows on human resource and university education in Africa. In historical perspective, brain drain in Africa dates back to the $16^{\text {th }}$ century when the first batch of millions of Africans was brought to the New World as slaves. The second incidence of brain drain was when a group of Africans willingly immigrated to the U. S. These were the children of the most educated and affluent segments of African society - the doctors, lawyers, university professors who freely migrated and are still migrating to U.S. and other countries of Europe for studies and for settlement. Globalisation has debilitating effect on Africans; those who leave, most often fail to come back.

\section{Issues}

\subsection{Conceptual Frame work}

Globalisation is the flow of technology, economy, knowledge, people, values, ideas etc across borders [11]. Some see globalisation as the force behind the changes taking place in higher education across the globe. It is the concept with which huge economic, political, and cultural changes that characterise human society at the turn of the century are interpreted. Another writer pointed out that globalisation is the process by which the capitalist world system spreads across the actual globe [16]. It constitutes an emergent form of Western imperialism carried through cultural institutions such as education [6]. Globalisation is somewhat the definitions above. The capitalist West puts the process of globalisation in place to perpetuate its economic influence across the globe. That it perpetuates this process only means that all spheres of social life must establish their positions in relation to it, making western capitalism a reference point against which nation states establish their policy options. The study opines that globalisation is indeed Western Imperialism through which the developed countries attract brains from across the globe. The study highlights the plight of Universities in Africa in relation to scapes and flows of globalisation.

\subsection{African Education and Colonisation}

The study notes that the problem of brain drain which African universities experience today is rooted in her historical past. The first incidence of brain drain occurred as a result of colonisation through slave trade when talented Africans were carried away as slaves, during the slave trade, to the New World. Advances in production and incentive for long distance trade stimulated Europeans to reach other parts of the globe, and the strength and cream of African human resource was depleted. This is supported by capitalism and the Marxist theory, which posit that capitalism has not only failed to develop nonWestern economies, but has made them worse off through economic restructuring. Capitalism, as a result of economic restructuring, led to various scapes and flows. The World system theory notes that globalisation is the 
process by which the Capitalist world system spreads across the actual globe. Europeans started this economic pursuit and exploited the rest to re-shape the world in their capitalist image. The world as a whole is now devoted to endless accumulation and profit-seeking on the basis of exchange as a market that treats goods and labour as commodities [16]. Today globalisation has given rise to the emergence of supranational institutions as well as neoliberalism. The study argues that in promoting neo-liberal policies, the state has withdrawn its responsibility of administering public resources to promote social justice. Nations are overtaken by global competition and responses to IMF demands, which neglect internal needs like education and welfare etc. Africa's talented brains further migrated to Europe and America during the postcolonial era, in their thousands and today with globalisation pressure, scapes and flows, millions of Africans have left to developed countries.

\subsection{Human Resource and Development in Globalisation Era}

It was explained that in the 21 st century global market that the richer countries attract and retain the world's best brains through effective policies that stimulate research and development activities, which increase direct investment, offer attractive post-graduate training and research opportunities, and recruit younger graduates and professionals [4]. For lack of opportunity and globalisation flows, Africa's talented brains are available. Australia, Canada and European Union members open recruitment offices in countries including African countries; France and Germany had freed up the issuance of visas to attract foreign professionals in technologyrelated areas. In October 2002, the U.S. introduced an amendment to its immigration laws that made available 600,000 new visas for scientists and engineers. These developed countries invest lots of human and material resources into research and publication and that is the secret of their development. Research and publications are continuous educational activities for them. Through research and publication, they transform their societies, not minding the amount of resources involved and they enjoy the benefits of these academic pursuits. These benefits accrue from advancement in research and development, science and technology, new technologies and innovations. Progress in agriculture, health, and environmental sanitation involves application of scientific innovations. Training qualified adaptable labour force, including high level scientists, professionals, technicians, personnel for civil service and business leadership are part and parcel of activities engaged by universities all over the world. The financial implication is tremendous. Many African governments do not make available the type of money needed for the kind of researches that make for sustainable development. They therefore cannot reap the type of benefits that accrue from such academic endeavour, and their talented brains migrate to places where the resources abound.

Middle income countries like China, Argentina, Indonesia etc resort to the World Bank IMF largest loans to fund universities in their countries. These countries experience high economic growth, reduced incidence of poverty, a rise in the average wage, an increased share of trade in GDP and improved health out come. In the OECD, member nations invest in the things that make up knowledge base, research and development, education, computer software etc. It was reported that member countries of the OECD account for $85 \%$ of total investment in research and development. China, India, Brazil and the newly industrial countries of East Asia (Malaysia, Singapore etc) account for $11 \%$, while the rest of Africa accounts for 4\% [17]. That Africa is marginalised in the global competition is clear from the above figures.

\subsection{African Universities and Globalisation in Relation to Brain Drain}

Globalisation is an uneven process, with unequal distribution of benefits and losses. It is a process that has divided the world into the 'haves' and 'have-nots'. It was lamented that this imbalance leads to polarisation between the few countries and groups that gain and the many countries and groups in society that lose out and are marginalised. Globalisation has led to the reframing of policies and operations of higher education globally. Globalisation, polarisation, wealth concentration and marginalisation are linked through the same process. In this process, investment resources, growth and modem technology are focused in a few countries in North America, Europe, Japan and East Asian new NICs [10]. It was reported that over the past three decades, only 15 countries have enjoyed high growth, while 89 countries were worse off economically than they were 10 or more years earlier. According to the report, economic gains have greatly benefited a few countries at the expense of many. Since 1980, 15 countries (mainly Asian) have had growth rates much higher than any seen during industrialisation in the West [7]. The 'lost decade' of the 1980s is in effect, still continuing for hundreds of millions of people in many countries of Asia, Africa and Latin America. In some cases, people are poorer than they were 30 years ago, with little hope of rapid improvement.

The forces of globalisation have subjected African nations to a state of absolute poverty and marginalisation from world economy and education. Many African nations do not benefit from opening their economies despite the well-publicised claims of export and income gains. The economic losses and social dislocation that are being caused to many developing countries (especially Africa) by rapid financial and trade liberalisation, the growing inequalities of wealth and opportunities arising from globalisation; and the perception that environmental, social and cultural problems have been made worse by the workings of global free-market economy, cannot be quantified. It has created social, economic, political and educational inequalities in the entire continent. All over Africa the main focus of the process of globalisation that was implemented since the 1980s was Structural Adjustment- the SAP. African nations are indebted and impoverished as a result of international institutions like IMF. Debt repayment pushed governments to embark on drastic measures, like rationalisation of workers. Other crucial aspects of life like (education, health, social welfare, etc) were neglected. The stage was set for human flight which has been one of the 'deadliest blows' of globalisation on African universities and society. Nations 
that took the loan (Nigeria, Uganda, Botswana, Malawi, Kenya as well as universities in the Caribbean, Latin America, and Asia etc) face the same dilemma. Inadequate funding brought about austerity. It has been succinctly described as "...declining morale, flight of talents, poor libraries, ill-equipped laboratories, and the open and shut campus syndrome etc. [1]." Thus, African universities face problems of declining standards and relevance in research \& publication, poor conditions of service of staff, unavailability and poor conditions, and out datedness of available equipment, frequent strike action, and threat to university lecturers, all resulting to human flight. This malady deprives African Universities of their most gifted/ talented brains.

\subsection{Brain Drain (Flight of Talents) in Perspective}

That African universities have lost and are still losing their most gifted brains especially when African governments took the IMF is not an over- statement. They suffer from overcrowding and staffs are being lured away to Western countries by higher pay and better conditions of service. The warning that Africa will be empty of brains in 25 years reflects the growing alarm over Africa's increasing exodus of human capital. Statistics show a continent losing the very people it needs most for economic, social, scientific and technological progress. Within 20 years, 127,000 highly qualified African professionals left the continent [14]. Africa has been losing 20,000 professionals each year since 1990, according to International Organisation for Migration (IOM). This trend has sparked claims that Africa is dying a slow death from brain drain. It has also been recognised by the UN that emigration of African professionals to the West is one of the greatest obstacles to sustainable development in the continent.

Economic Commission for Africa (ECA) has it that several professionals reside outside Africa and the distribution by country of origin is as shown in Table 1.

Table 1. Migration by Country of Origin

\begin{tabular}{|c|c|c|}
\hline Country of Origin & Period & Percentage \\
\hline Ethiopia & $1980-1991$ & $75 \%$ \\
\hline Ghana & $1990-2000$ & $54 \%$ \\
\hline South Africa & $1991-2000$ & $22.6 \%$ \\
\hline Nigeria & $1990-2000$ & $67.3 \%$ \\
\hline
\end{tabular}

Sources: Economic Commission for Africa (ECA) and US Census

Bureau Statistical Abstract, Washington DC 2003

Brain drain has strangled growth in Africa; it has nurtured poverty and delayed economic and sustainable development. EAC databank helps reach $15.8 \mathrm{~m}$ Africans living outside Africa mainly in Europe and North America (http://maps.google.com.ng/maps?q=Africans\%20living\% 20Germany@aq=f\&um=1\&e=utf=) The fact has been outlined that Nigeria represents one of the largest groups who immigrate. He pointed out that there are between 650,000 - 1,000,000 immigrants and that about 100,000 Nigerians are living in Houston, Texas vicinity alone [9]. These Nigerians have organised themselves along professional, ethnic and regional lines. Notes were compiled that 2,100 doctors were practising in the U.S. in mid 1990s and that there is an association of Nigerian Physicians in America [15]. Nigeria has lost over 20,000 medical doctors [12].
It was further pointed out that racial discrimination is now illegal. Bigotry is abhorrent, giving way for the advancement of African people in all fields of endeavour. One is now United States Secretary of State, the other is the Presidential National Security Adviser. In the past decade, African-Americans have held some of the most powerful political positions in the U.S. Today an African is American's number one man; in fact, the number one man in the whole world. Oprah Winfery is one of the most accomplished ladies in the world and she is an AfricanAmerican. Virginia, Maryland and Georgia, are predominantly made up of Igbos [9]. They were among one of the common ethnic groups found amongst enslaved Africans in America. Igbo people arrived in America through migration, one of the reasons being Nigeria's poor infrastructure and the effects of the Biafra-Nigerian war. It has been reported that one of the leading Computer Experts in the world, best known as Nigerian-born supercomputing pioneer, is an African (Nigerian) and resides in the U.S. [3]. He migrated shortly after the Biafra -Nigeria war. It is also pointed out that the African-American community is expected to reach 45 million by 2020 . African-owned businesses have multiplied; Africans have more access to higher education in the U.S. It is on record that 300, 000- 500, 000 Africans are living in Germany, presently (http://en.wikipedia.org/wiki/demographics of Germany). The number of South Africans living in the United Kingdom was given as 600,000 (http://www.southafrica.co.uk).

South Africa's Minister for Education accused the British Recruitment Agency of 'raiding' the country in search of teachers. The Agency is promoting brain drain in Africa by attracting Africans. It was pointed out that African teachers were being recruited to save the situation in the British school system. It was also noted that Essex primary schools have become more dependent on overseas teachers usually lured through supply agencies, who spend a couple of years in Europe before returning [13]. It was concluded that Britain attracts teachers from Australia, South Africa, New Zealand and Canada. These recruitments are a drain on Africa's human resources.

\section{The Damage}

It is noted that brain drain could have a debilitating effect on national governing structures, management capacities, productive sectors, and tertiary institutions. Brain drain has wrecked terrible damage on African universities and the entire society. Human flight in Africa has financial, institutional, and societal consequences. Africa's institutions are increasingly dependent on foreign expertise. Foreign construction companies are employed in Nigeria for better services. Africa employs up to 150,000 expatriates at the cost of U.S. \$4bn a year [17]. The impact of skilled human resource migration from Africa to Western industrialised countries is costing the continent a lot. Africa is losing her human capital at such an alarming rate that some observers say that the continent is dying a slow death from brain drain. In all, an executive of the Economic Commission of Africa opined that if something is not done, in 25 years' time, Africa will be empty of her brains. 
It was reported that in 2000, almost 175 million people or $2.9 \%$ of the world's population were living outside their country of birth compared to 100 million or $1.8 \%$ of the total population who are migrating, as the global market strength is increasingly dependent on highly skilled professionals who are migrating. The migration of trained manpower is reflected in all professions from both public and private sectors, but the health sector is mostly affected due to basic health problems that prevail over Africa. The department of health professionals has eroded the ability of medical and social needs. Thirty-eight of the forty-seven sub-Saharan African countries fall short of minimum WHO standards of twenty physicians per hundred thousand people. African professionals leave behind health systems that are severely stressed: life expectancy is only 50 years, 162 children in 1000 die before their fifth birthday, only half access clean water resources. Further HIV/AIDS prevalence among those 1549 years old is estimated to be $8.4 \%$ and contrast adult HIV/AIDS prevalence exceeds $30 \%$. The continent is getting poorer and poorer every year; people are dying due to lack of basic health care and necessities, while skilled people flee out of their country leaving all the problems behind. Africa and Nigeria have the highest rate of maternal and child mortality in the whole world. Thus, a continuous outflow of skilled labour contributes to a widening gap in science and technology between Africa and other continents. Africa's share of global scientific output has fallen from $0.5 \%$ in the mid-1980s to $0.3 \%$ in the mid-1990s. There are more African scientists and engineers in the U.S. than in the entire continent [5].

The flight of professionals from Africa endangers the economic and political systems in several African countries. As Africa's middle class disintegrates, its contributions to the tax system, and employment and civil society disappear. Africa stands the risk of becoming home to even greater mass poverty [8]. Brain drain has deprived Africa of her place among the League of Nations for sustainable development.

\section{What will Africa Do?}

It was pointed out that despite its potentially farreaching consequences; brain drain has rarely been an explicit public policy concern. The reason for the benign neglect includes respect for human rights, such as freedom of movement and choice of employment in the Universal Declaration of Human Rights Article 13 and 23 [17]. Whatever justification, brain drain is a risk for tertiary education investments, especially in Africa. Thus efforts are being made to stem African brain drain. Repatriation was considered, but studies have shown that it will not work as long as African governments fail to address the nagging problems that make life impossible. The need for Africans to develop credible strategy for progress in the areas that led the professionals to leave Africa is highlighted. There is need for calm and peaceful atmosphere devoid of political intrigues, ethnicity, multiple standards, favouritism and mediocrity. The stage must be prepared for economic development. There should be a conducive environment to develop and expand their entrepreneurial talents. The contribution of African Diaspora is seen as a major step forward. NEPAD and AU have formally recognised the African Diaspora as a key player in tackling the problem. In 2003, the AU amended charter so as to encourage the full participation of African Diaspora. The African Diaspora is conscious of their moral, intellectual and social responsibility to contribute to Africa's development efforts [2].

Africa must tap these human and material resources that follow them in the countries where they reside, to help tackle the myriads of problems facing the African continent and the problem of scientific and technological innovations must be tackled seriously. The question of environmental degradation, food, security, energy supply, portable water, HIV/AIDS, equitable economic growth for sustainable development, formidable educational system and adequate funds should be addressed. Governments should provide jobs for the learned fellows. Africans are paid peanuts in their own countries while expatriates are hired, who bag millions of money; provision should be made for experts.

\section{Conclusion}

Africa's talented brains migrate in search of "greener pastures". They go to places where conditions are conducive and needed equipment for scholarly productivity and work are in place. A major cause of the problem is inadequate funding. Thus African universities can improve if adequate funding is ploughed into the system and better conditions of service and necessary equipment put in place. Given these improved conditions, the talented brains will stay and those in Diaspora will return and contribute to the development of the continent.

\section{References}

[1] Akinkugbe, 0. 0. (2001). "The Piper, the Tune and University Autonomy". The Nigerian Social Scientist, 4(1); 2-6, March.

[2] Anani, K. "Q \&A - The World Bank and the African Diaspora." The World Bank, 2008.

[3] Fritz Holznagel and Paul Hehn. "Philip Emeagwali," Who2. [Online] Available: http://www.who2.com/bio/philip-emeagwali [Accessed Nov. 8th, 2012].

[4] Glanz, J. (2001) Trolling for Brains in International Waters in World Bank (2002). Constructing Knowledge Societies: New Challenges for Tertiary Education. Washington D.C.: World Bank

[5] Hagopian, A. et. al (2004). "The migration of physicians from sub-Saharan Africa to the United States of America: Measures of the African brain drain," Human Resources for Health. [Online] Available:

http://www.human-resources-health.com/content/2/1/17. [Accessed Nov. 8th, 2012]

[6] Henry, M. Lingard, B. Rizvi, F and Taylor S.(2008) The OECD, Globalisation and Education Policy, Emerald Publishers Ausralia

[7] Human Development Report (1996). Rising Inequality and the Effects of Globalization in Khor (2000). Globalisation and the South: Some Critical Issues. Ibadan: Spectrum Books Ltd.

[8] Human Resource For Health (2004). Brain Drain http://www.dramated.org/forum/viewtopic Accessed February 19, 2009.

[9] Jeter, Howard F. (2003). Reaching Out to The African in Diaspora: The Need for A Vision. Lagos: Centre for Black and African Arts and culture (CBAAC)

[10] Khor, M. (2001). Globalisation and The South: Some Critical Issues. Ibadan: Spectrum Books Ltd.

[11] Kritz, M. (2006). Globalisation and Internationalisation of Tertiary Education. Paper presented at symposium on International Migration and Development 
[12] Okojie, O. (2012). "Brain Drain," Lifestyle News. [Online] Available:

http://www.informationng.com/2012/07/brain-drain-nigeria-haslost-over-20000-medical-doctors.html

[13] Smith, R.(2011). African Countries Losing Doctors in 'Brain Drain.' [Online] Available:

http://www.telegraph.co.uk/health/healthnews/8912781/Africancountries-losing-doctors-in-brain-drain.html [Accessed Feb. 13th, 2013]
[14] Tebeje A. (2004) "Brain Drain and Capacity Building in Africa." International Development Research Council (IDRC), 2005. [Online] Available: http://www.idrc.ca/en/ev-71249-201-1-DO_TOPIC.html

[15] UNDP. 2002. Human Development Report: Deepening Democracy in a Fragmented World. Geneva: UNDP.

[16] Wallerstein, I. (1974-1989). The Modern World System (3 volumes). New York: New York Academic Press.

[17] World Bank (2002). Constructing Knowledge Societies: New Challenges or Tertiary Education. Washington D.C.: World Bank 